\title{
Distribution of Pelagic Elasmobranchs Caught by Salmon Research Gillnets in the North Pacific
}

\author{
Hideki Nakano and Kazuya Nagasawa \\ National Research Institute of Far Seas Fisheries, \\ Orido, Shimizu, Shizuoka 424, Japan \\ (Received December 14, 1995)
}

\begin{abstract}
The distribution of pelagic elasmobranchs was analyzed using bycatch data from the high seas salmon surveys by research gillnets from 1981 to 1991 in the North Pacific Ocean and the Bering Sea. Five species of sharks and one stingray were reported. Blue and salmon sharks and spiny dogfish were dominant and constituted $98 \%$ of the total shark catch. It is considered that the research area includes the southern part of the distribution for spiny dogfish and salmon sharks and the northern part of that for blue, shortfin mako, cookiecutter sharks and pelagic stingrays. These elasmobranchs showed spatial segregation by species in distribution according to oceanographic conditions. Intraspecific sexual and growth dependent segregations were also confirmed. Length frequency distributions of blue and salmon sharks suggest that their nursery grounds exist around the transitional domain of the subarctic boundary.
\end{abstract}

Key words: distribution, elasmobranchs, salmon survey, segregation, nursery ground, North Pacific

The Japanese high-seas salmon fishery ceased in 1992 after some 40 years of industrial fishing from 1952 because of international concern about the impact of this fishery upon the oceanic ecosystem. The Fisheries Agency of Japan has conducted salmon research for the rational use of salmon stocks for a long time. It also started bycatch research in the $1970 \mathrm{~s}$ using several research vessels. Bycatch research data collected by the research vessels of Hokkaido University and chartered vessels for scientific research from 1981 to 1991 were used for the present analysis. The research area is widely distributed from $35^{\circ} \mathrm{N}-$ $63^{\circ} \mathrm{N}$ from the northern coast of Japan to the Gulf of Alaska and the Bering Sea.

The spatial distribution and migration of pelagic elasmobranchs are still poorly known, although several surveys were conducted in the North Pacific Ocean. ${ }^{1-6)}$ Many of those studies partly described their distributions and migrations due to the limitation of research area, season and gear selectivity. Therefore, more detailed biological and ecological information is necessary for the conservation and stock management of pelagic elasmobranchs. This paper describes the distribution of pelagic sharks and rays in the North Pacific, north of the subarctic boundary.

\section{Materials and methods}

Sharks were caught using salmon research gillnets and commercial gillnets during the research periods. Salmon research gillnets consisted of 30 tan (tan is a unit of net in Japanese) and were a combination of 10 kinds of geometric series mesh size nets from $48-157 \mathrm{~mm}$, while commercial gillnets used 50 to 102 tan with $112-121 \mathrm{~mm}$ mesh size. One tan of net is about $50 \mathrm{~m}$ in length and $7-10 \mathrm{~m}$ in depth. The gear was set before sun set and retrieved near sun rise.
The date, position, number of tan used and number of catch by species were recorded for each fishing operation. Sea surface temperature (SST) at the surface was also recorded. Elasmobranchs caught during the research were salmon sharks Lamna ditropis, blue sharks Prionace glau$c a$, spiny dogfish Squalus acanthias, shortfin mako sharks Isurus oxyrinchus, cookiecutter sharks Isistius brasiliensis, and pelagic stingrays Dasyatis violacea. In general, precaudal length $(\mathrm{cm})$ by sex was recorded. Total length was measured for spiny dogfish and cookiecutter sharks, because these species do not have a precaudal pit.

The nominal CPUE (catch in number $/ 1,000$ tan) by $1^{\circ}$ latitude $\times 1^{\circ}$ longitude geographical area and by month (all years combined) was calculated for the analysis of distribution except for cookiecutter sharks and pelagic stingrays. The relation between CPUE by SST of each species was analyzed. Length frequency data of blue and salmon sharks were compiled by sex and by SST.

\section{Results}

\section{Research Period and Season}

A total of 2,923 salmon research operations were reported during 11 years from 1981 to 1991 (Table 1). The total research efforts were 320,810 tan and 3,986 sharks and rays were caught during the period. Blue shark catch was the largest, 2,498 in number, salmon shark the second (724), and spiny dogfish the third (667). These three species accounted for $98 \%$ of the total shark catch. The surveys were conducted from April to August but chiefly in June and July, which accounted for $70 \%$ of the total operations. Salmon sharks and spiny dogfish were caught throughout the season. Blue and shortfin mako sharks were caught from April to July. Few cookiecutter sharks and pelagic stingrays were caught, 7 and 4 each, from June 
Table 1. Catch of elasmobranchs caught during salmon research cruises from 1981-1991

\begin{tabular}{|c|c|c|c|c|c|c|c|c|c|c|c|c|}
\hline $\begin{array}{l}\text { Year } \\
\text { operation } \\
\text { effort }(\tan )\end{array}$ & $\begin{array}{r}1981 \\
287 \\
40739\end{array}$ & $\begin{array}{r}1982 \\
317 \\
40268\end{array}$ & $\begin{array}{r}1983 \\
322 \\
39858\end{array}$ & $\begin{array}{r}1984 \\
345 \\
45073\end{array}$ & $\begin{array}{r}1985 \\
261 \\
33946\end{array}$ & $\begin{array}{r}1986 \\
262 \\
25992\end{array}$ & $\begin{array}{r}1987 \\
262 \\
23625\end{array}$ & $\begin{array}{r}1988 \\
232 \\
21991\end{array}$ & $\begin{array}{r}1989 \\
224 \\
17020\end{array}$ & $\begin{array}{r}1990 \\
219 \\
17102\end{array}$ & $\begin{array}{r}1991 \\
192 \\
15196\end{array}$ & $\begin{array}{r}\text { Total } \\
2923 \\
320810\end{array}$ \\
\hline \multicolumn{13}{|l|}{ species } \\
\hline Squalus acanthias & 28 & 23 & 18 & 86 & 120 & 76 & 44 & 13 & 77 & 50 & 132 & 667 \\
\hline Isistius brasiliensis & 0 & 1 & 0 & 0 & 2 & 1 & 2 & 0 & 0 & 1 & 0 & 7 \\
\hline Isurus oxyrinchus & 0 & 2 & 4 & 3 & 12 & 14 & 5 & 13 & 6 & 0 & 1 & 60 \\
\hline Lamna ditropis & 182 & 160 & 46 & 92 & 74 & 26 & 48 & 29 & 24 & 13 & 30 & 724 \\
\hline Prionace glauca & 370 & 350 & 380 & 293 & 143 & 143 & 268 & 102 & 262 & 55 & 132 & 2498 \\
\hline Dasyatis violacea & 0 & 0 & 0 & 4 & 0 & 0 & 0 & 0 & 0 & 0 & 0 & 4 \\
\hline
\end{tabular}
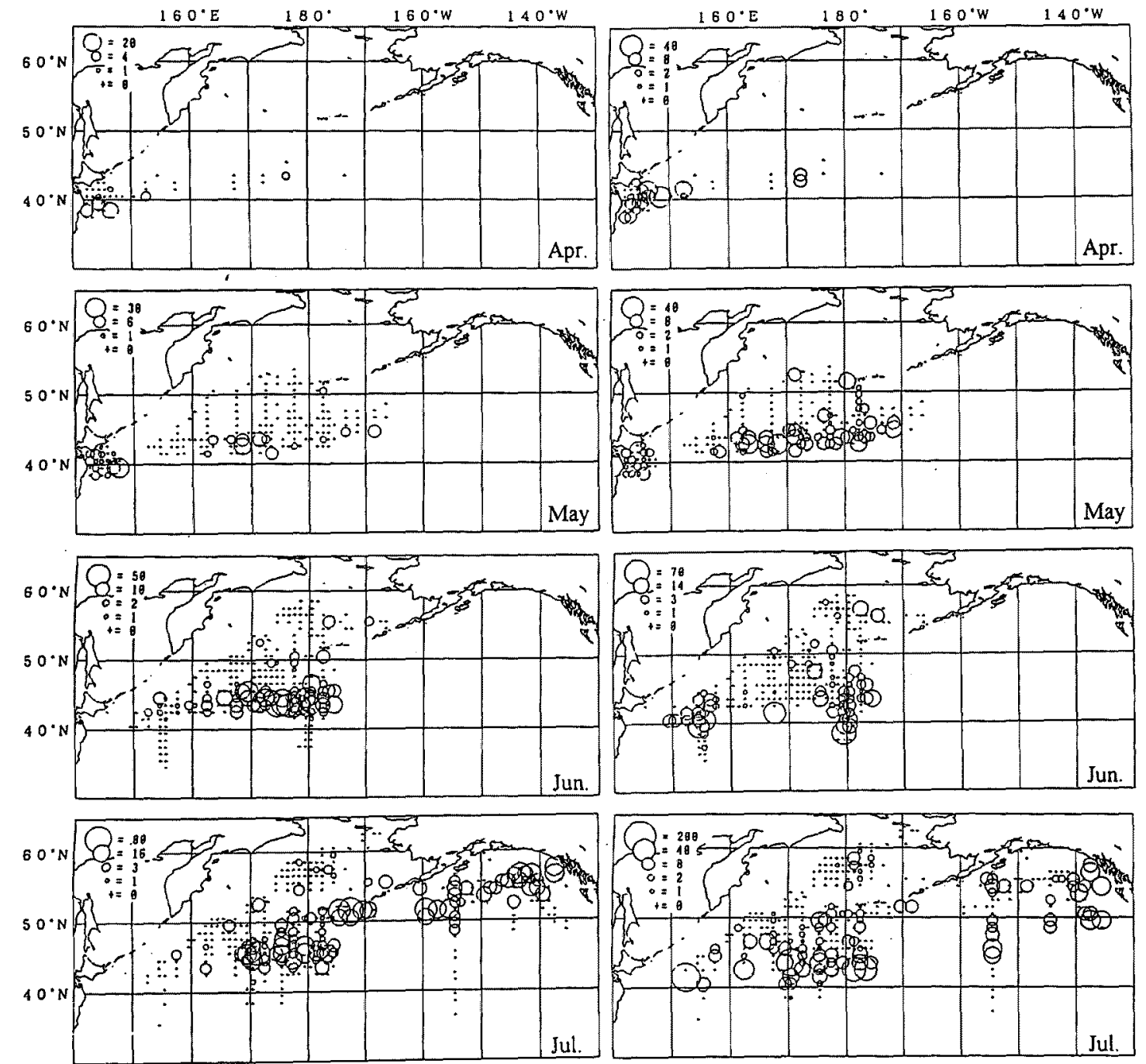

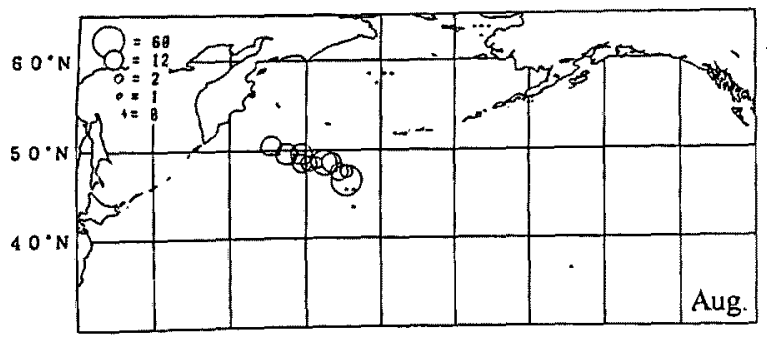

Spiny dogfish

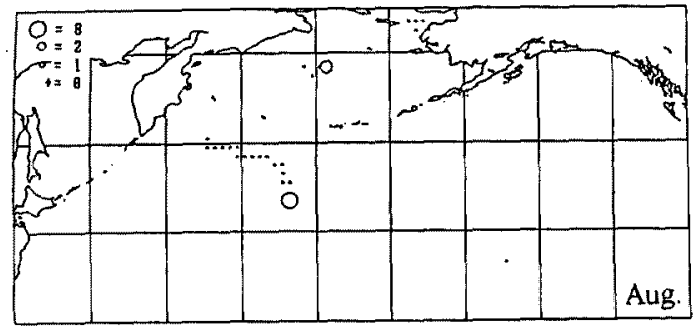

Salmon shark

Fig. 1. Average CPUE (catch in number $/ 1,000$ tan) distribution by $1^{\circ} \times 1^{\circ}$ geographical area during $1981-1991$ for spiny dogfish (left) and salmon sharks (right). 
to July, and in July, respectively.

\section{Geographical Segregation by Species}

Monthly average distributions of spiny dogfish and salmon sharks are shown as CPUE by $1^{\circ} \times 1^{\circ}$ geographical area in Fig. 1. Spiny dogfish occurred in four major areas i.e., off northern Japan, the open sea south of the Aleutian Islands, adjacent waters of the Aleutian Islands, and the Gulf of Alaska. Their high CPUE areas existed in a narrow latitudinal band, ranging from $42^{\circ} \mathrm{N}-52^{\circ} \mathrm{N}$ in the open sea south of the Aleutian Islands. Salmon sharks showed a similar distribution pattern as spiny dogfish, and high CPUE areas occurred somewhat to the south of the distribution of spiny dogfish with some overlapping.

Monthly distributions of blue and shortfin mako sharks are shown in Fig. 2. High CPUE areas of blue sharks appeared along the southern parts of the research area $34^{\circ} \mathrm{N}$ $48^{\circ} \mathrm{N}$ from offshore waters of Japan to the Gulf of Alaska. Shortfin mako sharks were caught at the south edge of the research area. The number of shortfin mako caught was small, 60 in total. Neither a clear high CPUE area nor movement was observed.

From the geographical analysis of CPUE distribution, a high CPUE band was noticed for each species. CPUE by SST also suggested segregation by species as is shown later. Spiny dogfish occurred in the northernmost part, followed by salmon, blue and shortfin mako sharks in order from north to south.

Few cookiecutter sharks and pelagic stingrays were caught. Cookiecutter sharks were caught at 4 stations in June and 3 stations in July, which were located, respectively, from $35^{\circ} 00^{\prime} \mathrm{N}-38^{\circ} 33^{\prime} \mathrm{N}$ and from $155^{\circ} 01^{\prime} \mathrm{E}-175^{\circ}$ $33^{\prime} \mathrm{E}$. Pelagic stingrays were caught only at two stations $\left(38^{\circ} 00^{\prime} \mathrm{N}, 155^{\circ} 00^{\prime} \mathrm{W} ; 39^{\circ} 29^{\prime} \mathrm{N}, 154^{\circ} 59^{\prime} \mathrm{W}\right)$ in July.

\section{Distribution Related to Sea Surface Temperature}

Since the depth of gillnet gear was only 7-10 $\mathrm{m}$ from the sea surface, the observed SSTs at sampling stations were considered fairly close to those of capture. CPUEs of sharks and rays by $1^{\circ} \mathrm{C}$ of SST are shown in Fig. 3. Opera-
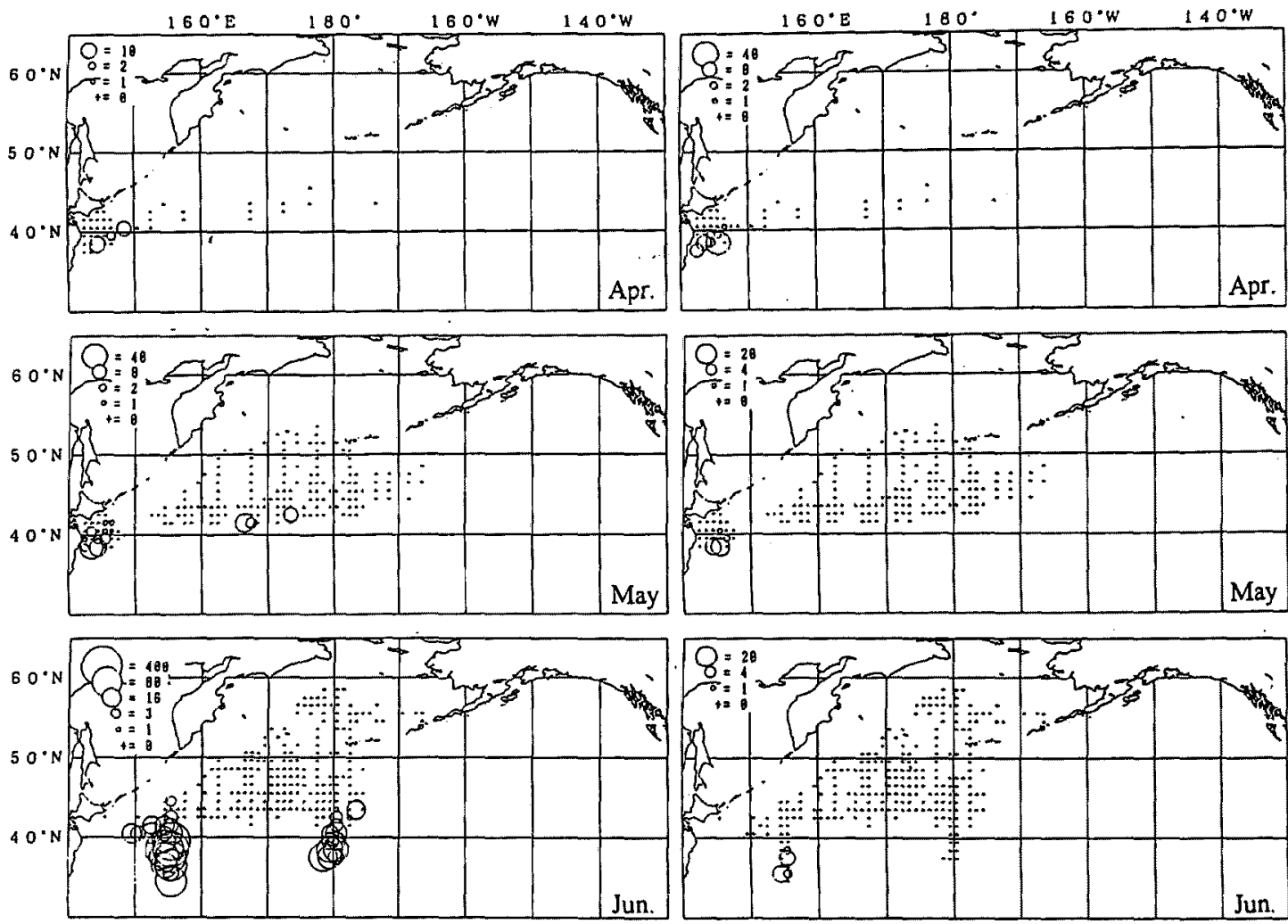

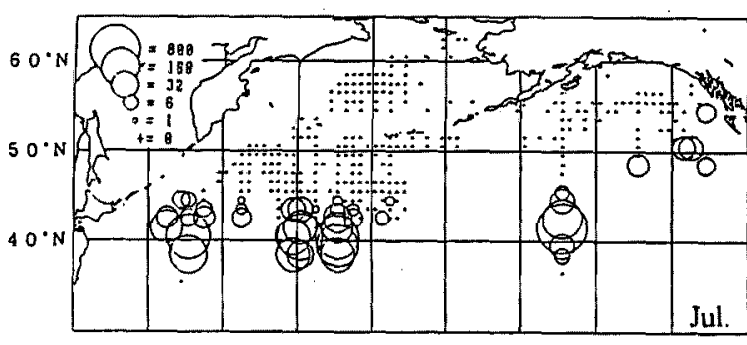

Blue shark

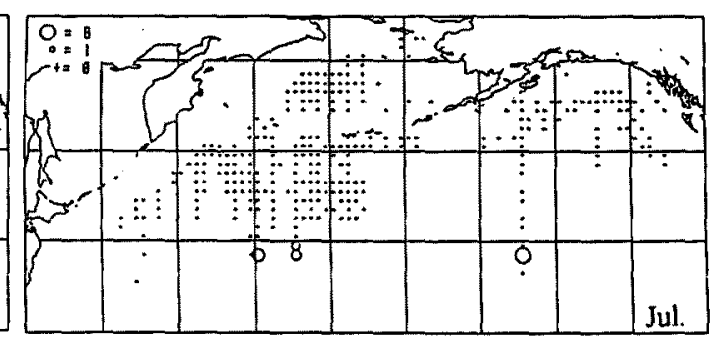

Shortfin mako shark

Fig. 2. Average CPUE (catch in number/1,000 tan) distribution by $1^{\circ} \times 1^{\circ}$ geographical area during 1981-1991 for blue sharks (left) and shortfin mako sharks (right). 

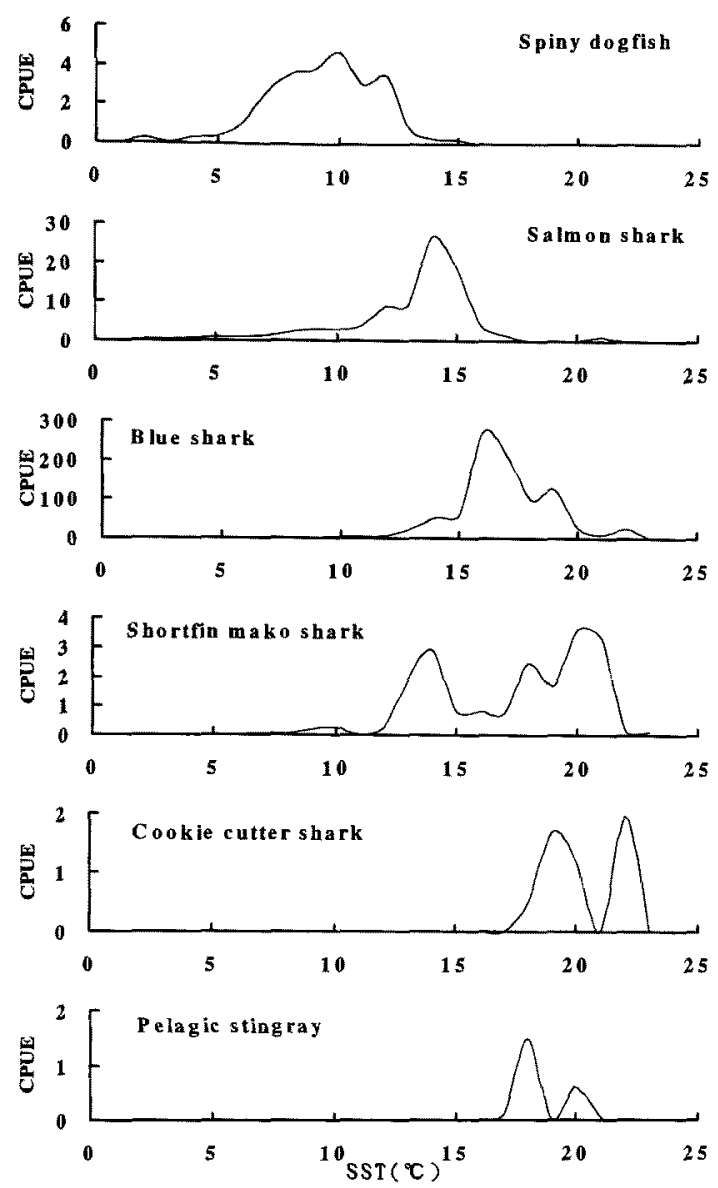

Fig. 3. CPUE (catch in number/1,000 tan) of pelagic elasmobranchs by sea surface temperature.

tions were conducted at SSTs ranging from $1.0-23.0^{\circ} \mathrm{C}$ and, a large proportion of the efforts was set at SSTs ranging from $3.0^{\circ}-11.0^{\circ} \mathrm{C}$. The spatial segregation by species appears to depend on SST. Spiny dogfish mainly occurred at $6.0^{\circ}-12.0^{\circ} \mathrm{C}$. High CPUEs of salmon sharks were observed at $9.0^{\circ}-16.0^{\circ} \mathrm{C}$. Blue sharks occurred in warmer waters, with high CPUEs at $13.0^{\circ}-22.0^{\circ} \mathrm{C}$. High CPUEs of shortfin mako sharks appeared at both $13.0^{\circ}-14.0^{\circ} \mathrm{C}$ and $18.0^{\circ}-21.0^{\circ} \mathrm{C}$. Cookiecutter sharks and pelagic stingrays occurred at SSTs above $18.0^{\circ} \mathrm{C}$.

\section{Distribution by Sex and Growth}

A total of 719 sharks (11 spiny dogfish, 78 salmon sharks, 621 blue sharks, 8 shortfin mako sharks, and 6 cookiecutter sharks; $18.2 \%$ of total catch) were measured. Spiny dogfish ranged from $51-75 \mathrm{~cm}$, salmon sharks from $70-185 \mathrm{~cm}$, blue sharks from $35-200 \mathrm{~cm}$, shortfin mako sharks from $70-130 \mathrm{~cm}$, and cookiecutter sharks from $45-$ $60 \mathrm{~cm}$.

Length frequency distributions of blue sharks by sex and by $2^{\circ} \mathrm{C}$ of SST are shown in Fig. 4. Blue shark females were caught at $8^{\circ}-21^{\circ} \mathrm{C}$ and males at $12^{\circ}-21^{\circ} \mathrm{C}$. Full-term sharks (below $50 \mathrm{~cm}$ ) were caught at $12^{\circ}-19^{\circ} \mathrm{C}$ for both sexes. Larger females over $90 \mathrm{~cm}$ were caught over a wide range from $8^{\circ}-21^{\circ} \mathrm{C}$, while larger males in warmer waters ranging from $14^{\circ}-21^{\circ} \mathrm{C}$ than smaller sharks. Larger fe-

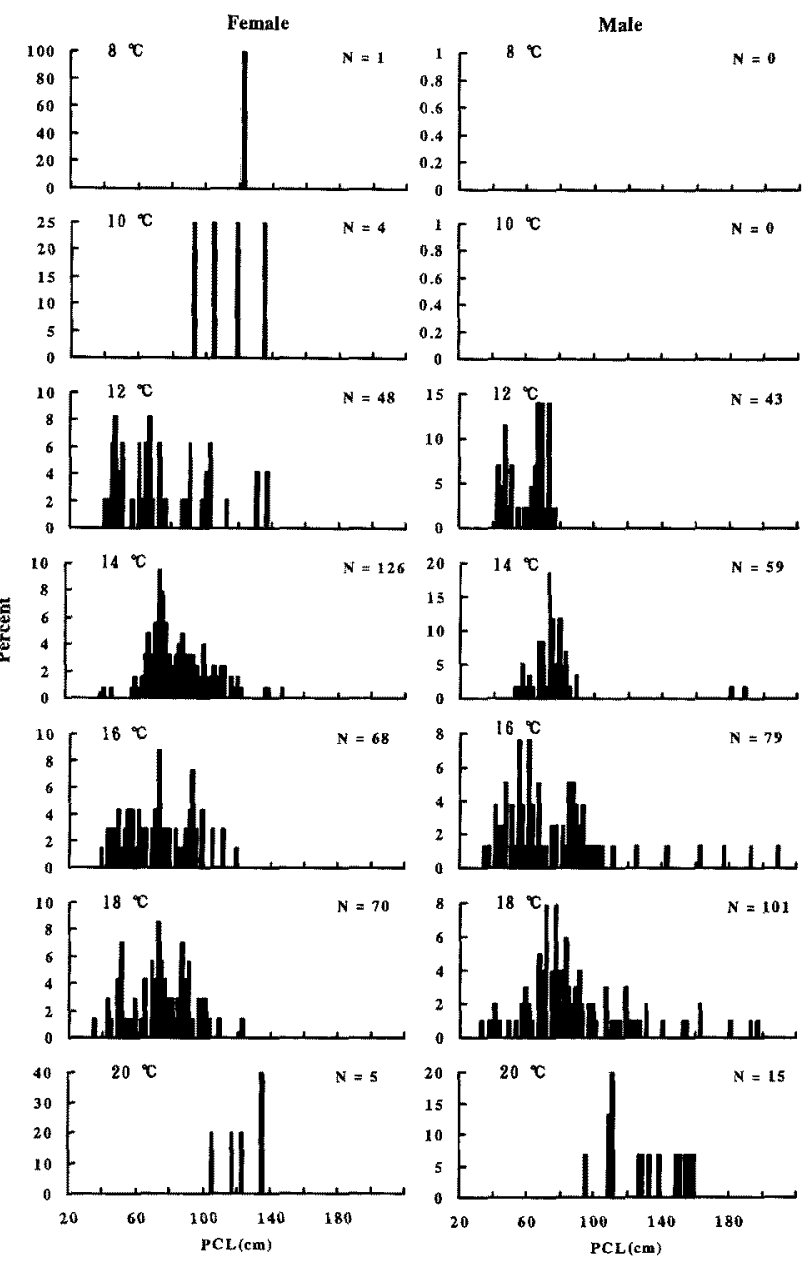

Fig. 4. Length frequency distributions of blue sharks by sex and by sea surface temperature.
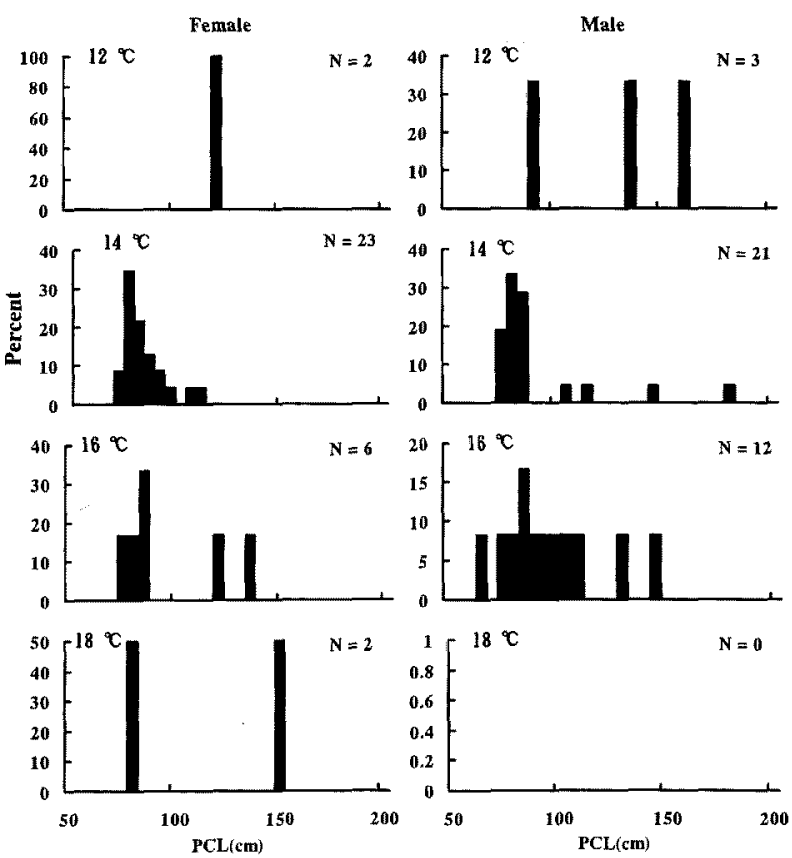

Fig. 5. Length frequency distributions of salmon sharks by sex and by sea surface temperature. 
males tended to occur in cooler waters than males.

Length frequency distributions of salmon sharks are shown in Fig. 5. Full-term sharks (below $100 \mathrm{~cm}$ ) were mostly caught at $14^{\circ}-19^{\circ} \mathrm{C}$ for both sexes. Larger sharks over $100 \mathrm{~cm}$ occurred over a wide range from $12^{\circ}-19^{\circ} \mathrm{C}$.

\section{Discussion}

Spiny dogfish are mainly distributed on the continental shelves of North America and northern Japan and are considered inshore species." However, Ketchen ${ }^{8)}$ reported their trans-Pacific migration: two spiny dogfish tagged off the west coast of Canada were recaptured in Japan. He also noted the distribution of spiny dogfish in the open sea in the North Pacific Ocean (off Japan, south of the Aleutian chain, and the Gulf of Alaska) based on the incidental catch records from Japanese, Canadian and United States research vessels conducting surface gillnet and longline explorations for Pacific salmon on the high seas during the summer months. The present study has proven that many spiny dogfish occurred in the open sea, ranging from north of $40^{\circ} \mathrm{N}$ to south of the Aleutian chain. Eleven spiny dogfish captured in the open sea $(59 \mathrm{~cm}$ for males and $51-$ $75 \mathrm{~cm}$ for females) are considered immature or just mature sharks, based on the reported mature size from both sides of the Pacific Ocean, i.e. about $70 \mathrm{~cm}$ for males and 72-94 $\mathrm{cm}$ for females. ${ }^{9,10)}$ It is possible that immature spiny dogfish extend their habitat to offshore waters and some of them use these waters for the trans-Pacific migration.

Salmon sharks mainly occurred in waters north of $35^{\circ} \mathrm{N}$ in the open ocean. ${ }^{4)}$ This species is abundant around the Aleutian Islands and south of $47^{\circ} \mathrm{N}^{5)}$ Blagoderov ${ }^{11)}$ described that smaller salmon sharks occurred south of their range and suggested that potential parturition grounds may be situated in open waters of the North Pacific, in- shore waters of both Japan and the southern Kuril Islands. The length frequency distributions by SST obtained in the present study indicate small salmon sharks $(70-110 \mathrm{~cm})$ were concentrated to a SST range from $14^{\circ}-16^{\circ} \mathrm{C}$, which were recorded from the north of the subarctic boundary in summer. This area is adjacent to a parturition ground supposed by Blagoderov. ${ }^{\text {(1) }}$ Therefore, the southern boundary area of their distribution is considered a nursery ground of this species (Fig. 6).

Blue sharks have a wide range of distribution from the equator to $55^{\circ} \mathrm{N}$ in the Gulf of Alaska. ${ }^{2,3)}$ The length frequency distributions by sex and by SST indicate both segregation by sex and growth patterns reported by previous researchers for large-sized sharks.,2) Nakano ${ }^{12)}$ made a migration model of blue sharks and indicated their nursery ground is located in the subarctic boundary area. Almost all blue sharks captured in the transitional domain and south of the subarctic boundary consisted of both young and immature sharks. The area where these blue sharks were captured is considered a nursery ground for the young.

The life history of shortfin mako sharks is not well known. The size at birth is about $70 \mathrm{~cm}$ in total length and parturition occurs in November off New South Wales, Australia in the South Pacific. ${ }^{13)}$ The small shortfin mako sharks caught by our research were fairly close to this birth size.

Little is known about the life history and distribution of cookiecutter sharks and pelagic stingrays. Cookiecutter sharks inhabit the bathypelagic and epipelagic zones of tropical to subtropical oceans. ${ }^{4)}$ Nakano and Tabuchi ${ }^{14)}$ showed their wide occurrence in the central North Pacific and indicated that the northern limit of their distribution is nearly equivalent to the south of the subarctic boundary. Considering this information, our specimens of

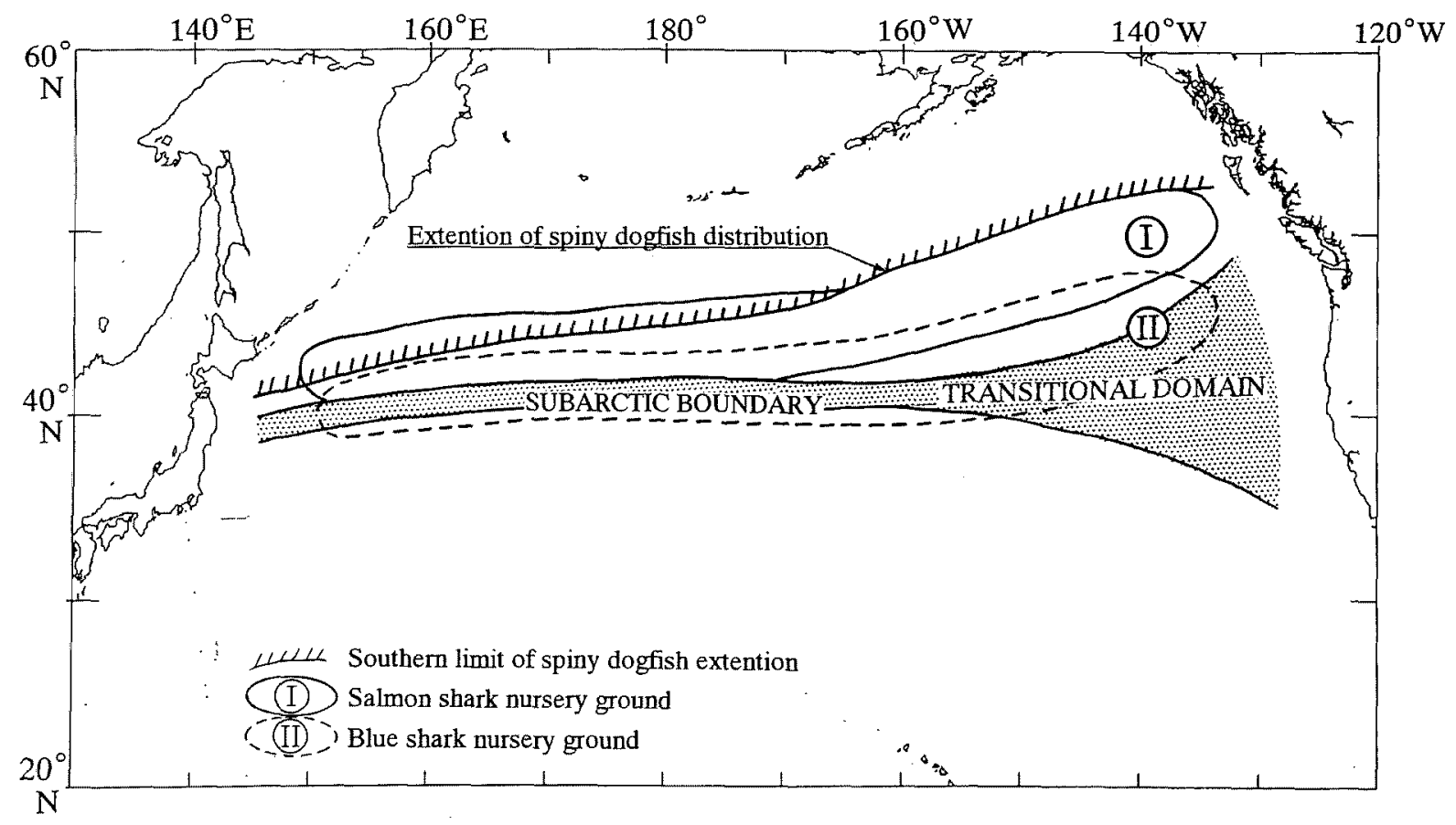

Fig. 6. Schematic map for supposed nursery grounds of salmon sharks and blue sharks in the North Pacific. 
cookiecutter sharks were captured at the northern edge of their habitat. Pelagic stingrays are often caught as bycatch of longline fishery of which the fishing ground is further south than our research area. ${ }^{15)}$ Although the distribution of pelagic stingrays is not well known, the locations of pelagic stingrays captured might indicate the northern edge of their habitat.

The subarctic boundary is a huge oceanic front existing between the subtropical and subarctic waters. The areas where epipelagic sharks and rays occurred are classified as follows by the oceanographic description of Dodimead et al. ${ }^{16}$ Spiny dogfish occurred in the subarctic region only. Salmon sharks were caught in the subarctic region and part of the transitional domain. Blue sharks were caught along the transitional domain and in the subtropical waters. Shortfin mako sharks appeared south of the subarctic boundary. Cookiecutter sharks and pelagic stingrays occurred only in the subtropical region. Following these results, it is considered that the research area includes the southern edge of their distribution for spiny dogfish and salmon sharks and the northern distribution limit for blue, shortfin mako, cookiecutter sharks, and pelagic stingrays.

It is interesting that a zone of high CPUEs by species around the transitional domain consists of both nursery grounds for salmon, blue, and mako sharks, and extension of the distribution of spiny dogfish (Fig. 6). It is also noticed that abundant pelagic sharks, such as salmon and blue sharks, have adjoining nursery grounds in the oceanic frontal area. Springer ${ }^{17)}$ noted with reference to the life history of inshore species that habitat segregation of elasmobranchs is adaptation for avoiding predation by large sharks including the same species. Similar segregations are noticed for the offshore species examined in the present study. These nursery grounds are separated from the adult habitats. Adult salmon sharks are distributed in the northern area, and adult blue sharks occur in southern waters. ${ }^{2,5,12)}$ Another adaptive advantage is that those sharks use a high productive area, such as the transitional domain and the subarctic front, as nursery grounds and get enough energy for growth. ${ }^{12)}$ Pearcy ${ }^{18}$ reviewed the biology of the transition region located between the subtropical and subarctic waters. He noticed that migrants can utilize the high productivity of the subarctic waters and feed on large nutritious prey, such as gonatid squids, Pacific saury, and sardine.

Acknowledgments We are grateful to the crews and scientific staff of the research vessels and the staff of the National Research Institute of Far Seas Fisheries and the Fisheries Agency of Japan who were involved in this research. Without their cooperation, the collection of catch data, as well as biological measurements would have been difficult.

\section{References}

1) A. Suda: Ecological study on the blue shark (Prionace glauca Linne). Bull. Nankai Reg. Fish. Lab. Rep., 26, 1-11 (1953) (in Japanese).

2) D. W. Strasburg: Distribution, abundance, and habits of pelagic sharks in the central Pacific Ocean. Fish. Bull., 58, 335-361 (1958).

3) F. Neave and M. G. Hanavan: Seasonal distribution of some epipelagic fishes in the Gulf of Alaska region. J. Fish. Res. Board Can., 17, 221-233 (1960).

4) N. V. Parin: Ichthyofauna of the epipelagic zone. Moscow: Academy of Sciences of the U.S.S.R. (Translated from Russian by Israel Program for Scientific Translations), Reproduced by the National Technical Information Service, Springfield, Virginia, 1970, p. 206.

5) O. Sano: The investigation of salmon shark as a predator of salmon in the North Pacific, 1959. Bull. Hokkaido Reg. Fish. Res. Lab., 22, 68-82 (1960) (in Japanese).

6) H. Nakano, M. Makihara, and K. Shimazaki: Distribution and biological characteristics of the blue shark in the central North Pacific. Bull. Fac. Fish. Hokkaido Univ., 36, 99-113 (1985) (in Japanese).

7) L. J. V. Compagno: Sharks of the world, FAO Species Catalogue Vol. 4, Rome, 1984, p. 248.

8) K. S. Ketchen: The spiny dogfish (Squalus acanthias) in the northeast Pacific and a history of its utilization. Can. Spec. Publ. Fish. Aquat. Sci., 88, 78 (1986).

9) M. Ukawa: Ecological research on the spiny dogfish, in "Report of the third symposium of development studies on Tsushima current" Fisheries Agency of Japan, 1955, pp. 119-126 (in Japanese).

10) K. S. Ketchen: Size at maturity, fecundity, and embryonic growth of the spiny dogfish (Squalus acanthias) in British Columbia waters. J. Fish. Res. Board Can., 29, 1717-1723 (1972).

11) A. I. Blagoderov: Seasonal distribution and some notes on the biology of salmon shark (Lamna ditropis) in the northwestern Pacific Ocean. J. Ichthyol., 34, 115-121 (1994).

12) H. Nakano: Age, reproduction and migration of blue shark in the North Pacific Ocean. Bull. Nat. Res. Inst. Far Seas Fish., 31, 141256 (1994) (in Japanese).

13) J. D. Stevens: Observations on reproduction in the shortfin mako Isurus oxyrinchus. Copeia, 1983, 126-130 (1983).

14) H. Nakano and M. Tabuchi: Occurrence of the cookiecutter shark Isistius brasiliensis in surface waters of the North Pacific Ocean. Japan. J. Ichthyol., 37, 60-63 (1990).

15) R. Ishiyama and K. Okada: A new stingray, Dasyatis atratus (Dasyatidae, Pisces), from the subtropical Pacific. J. Shimonoseki Coll. Fish., 4, 211-216 (1955).

16) A. J. Dodimead, F. Favorite, and T. Hirano: Salmon of the North Pacific Ocean-Part II. Review of oceanography of the subarctic Pacific Region. Bull. Int. North Pac. Fish. Comm., 13, 1-195 (1963).

17) S. Springer: Social organization of shark population, in "Sharks, skate and rays" (ed. by P. W. Gilbert, R. F. Mathewson and D. P. Rall), The John Hopkins Press, Baltimore, 1967, pp. 149-174.

18) W. G. Pearcy: Biology of the transition region, in "Biology, oceanography, and fisheries of the North Pacific transition zone and subarctic frontal zone" (ed. by J. A. Wetherall), NOAA Tech. Rep. NMFS, 105, 39-55 (1991). 